\title{
Reform paradoxes: academic freedom and governance in Greek and Turkish higher education
}

\author{
loannis N. Grigoriadis \& Antonis Kamaras
}

To cite this article: loannis N. Grigoriadis \& Antonis Kamaras (2012) Reform paradoxes: academic freedom and governance in Greek and Turkish higher education, Southeast European and Black Sea Studies, 12:1, 135-152, DOI: 10.1080/14683857.2012.661224

To link to this article: http://dx.doi.org/10.1080/14683857.2012.661224

曲 Published online: 13 Mar 2012.

Submit your article to this journal $\widetilde{ }$

III Article views: 209

Q View related articles $₫$ 


\title{
Reform paradoxes: academic freedom and governance in Greek and Turkish higher education
}

\author{
Ioannis N. Grigoriadis ${ }^{\mathrm{a} *}$ and Antonis Kamaras ${ }^{\mathrm{b}}$ \\ ${ }^{a}$ Department of Political Science, Bilkent University, Bilkent, Ankara, TR-06800, Turkey; \\ ${ }^{b}$ Municipality of Thessaloniki, Thessaloniki, GR-54640, Greece
}

(Received March 2011; final version received 7 February 2012)

\begin{abstract}
This study evaluates the impact of higher education reforms, implemented in the early 1980s in Greece and Turkey, due to preceding student and wider political radicalization, on academic freedom. It highlights a paradox, namely that authoritarian corporatism in Turkey inadvertently facilitated academic freedom in higher education, whereas in Greece participatory majoritarianism ended up stifling academic freedom. Authoritarian corporatism in Turkey mandated the introduction of private universities. These expanded academic freedom within the wider national goal of the country's European Union membership. Participatory majoritarianism in Greece conversely mandated student organisation participation in the governance of Greek higher education. These acquired powerful rent-seeking interests, which have progressively constricted academic freedom.
\end{abstract}

Keywords: Greece; Turkey; academic freedom; higher education; private; public

\section{Introduction}

Student radicalization in the 1970s engendered opposite reactions in Greece and Turkey. In Greece, it helped usher the transition to democracy in 1974, while in Turkey it served as pretext for the 1980 military coup. These contrasting reactions also engulfed the two countries' respective university systems and governance arrangements in due course. In Greece, the defining thread of reforms in higher education governance was that of participatory majoritarianism, in Turkey of authoritarian corporatism. This paper will argue that paradoxically it was authoritarian corporatism in Turkey that facilitated academic freedom in higher education, whereas in Greece participatory majoritarianism ended up stifling it.

For the purposes of our investigation, this study adopts the constitutive elements of academic freedom identified by a survey of the concept relating to a templatesetting exercise in European higher education (Karran 2009, 169-70). These constitutive elements comprise: (i) the freedom conferred to academics to pursue teaching, research and the publication of the latter without outside hindrance imposed on these activities, (ii) the freedom conferred to academics to pursue lines of inquiry that challenge conventional wisdom, originate and partake in debate that can cause umbrage and unpopularity, without fear that they might be deprived of their jobs and the privileges attached to them.

*Corresponding author. Email: ioannis@bilkent.edu.tr 
As it will be seen below, the aimed contribution of this paper would be to expand and qualify this definition so as to incorporate, in the factors inimical to academic freedom, not only specific higher education governance arrangements that would either threaten or safeguard academics from exercising that sort of freedom, but wider material and normative factors that could have the same effects. In that respect, our investigation is a constructivist one, sensitive to both material interests as well as ideational assumptions, which enjoy hegemonic power in the Greek and Turkish polities within which the compared higher education systems are ensconced. By doing so, this study challenges accounts that view either faculty participation in university administration as a bulwark supporting academic freedom (Vere 2007, 2) or student participation in academic affairs as engendering a consensus which can facilitate and inform evolution in higher education undertaken by academics (Menon 2003, 244). This study aims to utilize but also to extend the reach of analyses, either general or pertaining to the Greek case that highlights the effects of participation of such stakeholders as student unions as capable of promoting gridlock, filibustering and rent-seeking in higher education, to the detriment of academic freedom. In this respect, a key contribution of this study is the reaffirmation of the need to examine institutional performance, and in particular the interaction between governance and academic freedom in higher education, in a nonformalistic way. Instead of taking into account the nominal and institutional characteristics of higher education systems in determining whether they are conducive or not to a particular feature of these systems, such as academic freedom, it is argued that the material and normative characteristics of the polities and actors that are capable of shaping higher education should be the focus of analysis. The eventual outcomes of higher education reforms were directly contrary to the nominal and perceived intent of the policy-makers which instituted these reforms, the comparison and evolution of which is the subject matter of this paper. The wider utility, beyond these two country cases of Greece and Turkey, will be to establish the case for a qualitative, single-case approach in the examination of higher education systems particularly in middle development countries, with a recent authoritarian tradition, before attempting a quantitative analysis of this cohort.

Our research is also pertinent to the debate on the Arab Spring's consequences on higher education. ${ }^{1}$ In particular, the compromised position of academic leaderships, due to their regime affiliations, in such countries as Egypt and Tunisia, have fuelled demands both for depoliticisation of higher education in these counties and for greater student involvement in higher education governance. Reversely, the recent growth of a private higher education segment in the region will also present an enticing possibility for the use of this segment for the re-consolidation of political docility in universities, particularly in Arab regimes which would end up successful in repressing political rebellion. In the analysis that follows, both the Greek and the Turkish case illuminate the potential outcomes of either one of these two paths.

This study will commence with an evaluation of the origins and nature of higher education reforms undertaken in Greece and Turkey in the early 1980s. These share in common the attempt to address the expansion and concomitant radicalization of these two higher education systems. The Greek effort sought to render sacrosanct the idea of the university as an inviolate space, whereby Greek authorities such as the police could only enter under the invitation of university authorities. Additionally, students, the associational activities of whom were suppressed during the 
preceding seven-year rule of the military dictatorship, were given the right to comanage the university, up to and including the determination of when could Greek police enter the university space, with the universities' rectors and senates. The Turkish effort was designed to de-radicalize the Turkish university, under the auspices of the country's military overseers. The Turkish reforms also introduced new players, namely private benefactors that would set up universities of their own, but within the context of the country's authoritarian cum corporatist tradition, which saw them as supporting pillars of the regime.

In the succeeding two decades, the 1990s and 2000s, which will be the focus of this study, privately run universities in Turkey, sponsored mainly by the country's leading business families, coupled their academic freedom and self-governance with the wider national goal of the country's European Union (EU) accession process. As such, they became citadels of a pluralistic discourse that would come to challenge the orthodoxies of the Turkish Republic, in terms both of its provenance and its contemporary practice on such explosive issues as the treatment of minorities. Consequently, Turkish higher education, and in particular its privately-run segment, has made definitive advancements in the domain of academic freedom, in a polity where democracy is not nearly as well consolidated as it is in Greece. By contrast in Greece, higher education's governance arrangements that confer decisive power to political student organizations, sanctified as they have been in public discourse by the student contribution to the 1974 democratic transition, have allowed for continuous and widespread disruption in the normal operations of the Greek university. This has actually compromised academic freedom, the purported key objective of the 1982 reforms.

\section{The 1980s reforms: origins and outcomes \\ The case of Turkey}

In Turkey, given that public universities had been leftist strongholds during the turbulent 1960s and 1970s, the 1980-1983 military regime aimed to 'depoliticize' higher education, by bringing state universities under much more intrusive central government control than hitherto had been the case. The relevant legal framework was amended in 1981 whereby the Higher Education Council (Yüksek Ögrretim Kurulu $[\mathrm{YÖK}]$ ) was resurrected and reconstituted as a national board of governors responsible for the nomination of rector candidates and the appointment of deans. Furthermore, the powers given to YÖK through the new legislation allowed for the removal of hundreds of dissident faculty members from state universities. YÖK also assumed extensive supervisory powers over curriculum development and all future faculty appointments in the state university system in Turkey. Essentially, the reformed YÖK became the tool for the re-imposition of official state ideology upon universities. However, only one year later, in 1982, the constitutional stipulation setting a state monopoly on higher education was lifted, and the establishment of private non-profit foundation (vaklf) universities became possible, despite initial judicial opposition. Private foundations were allowed to establish universities, provided they are non-profit, adequately endowed and that the standard of teaching and research was no lower than that of public universities. What explains this - at least on surface - contradiction between the military regime's assertion of control over higher education and contemporaneous liberalization? 
In fact, higher education reform - both by eliminating the autonomy of state universities and enabling the creation of private ones, presumably enjoying greater freedom of action than even state universities did prior to the institution of the allpowerful YÖK - had a single aim: the emergence of a depoliticized tertiary sector dedicated to Turkey's developmentalist goals. The emergence of private higher education institutions committed to Turkey's economic development and loyal to the regime's ideology and vision posed additional pressure upon state universities whose allegiance to official state ideology had been suspected. While state universities were losing their monopoly and were undergoing a major transformation, these new private academic institutions were founded by corporate actors who were assumed to be loyal and compliant with key regime goals. They were expected to become bulwarks of the official state ideology and contribute to the realization of its developmentalist orientation. This was an eminently realistic assumption, as, within Turkey's statist paradigm, and in an economy where corporate fortunes rose and fell depending on their access and influence to the state and its functionaries, any sort of civic activism undertaken by Turkey's corporate families had to be indisputably loyal to the Republic's orthodoxy. Such fealty was institutionalized, as these corporate actors, in the charitable foundations that they had established earlier in the 1970s, took great pains to establish their regime-friendly credentials and intentions, by appointing in their boards, key - if retired - figures from Turkey's bureaucratic and armed forces establishment (Singer 2008). Importantly, the university reform prescribed a governance structure for the private universities premised on powerful Boards of Trustees - as opposed to faculty self-governance - accountable in turn to YÖK.

An increasing number of private universities were founded, and 62 of them were operating in 2011, alongside 103 public universities. From them emerged some of the leading academic institutions of Turkey, such as Bilkent University, Sabancı University and Koç University, the latter two founded by the country's two biggest business conglomerates.

The reforms of 1982 - both in terms of state control through YÖK of state universities, putting limits to academic freedom and allowing the establishment of private universities - essentially were and became part of a continuum, at least until the mid-1990s, with the Turkish Republic's authoritarian and corporatist character (Küçükcan and Gür 2009, 137-40). This continuum actually predated the crisis of the 1970s that brought them into being. Heper (1985) has pointed out how continuous failure to reconcile Turkey's cleavages, socio-economic, religious and ethnic ones has renewed the mandate and ability of the state apparatus to act as an overseer over the political process. Özbudun 1991 and Bianchi (1984) have analysed extensively how associational and civic life has been periodically subjected to state intervention. More recently, Parla and Davinson (2004) have posited that Kemalism, as a 'third way' ideology of authoritarian corporatism has endured in Turkish collective life, delegitimizing any kind of collective or corporate action that does not purport to serve the nation. The nation itself is perceived, in classic authoritarian and corporatist terms, as an entity which is assumed to reconcile all class and sectarian differences under its imperatives of modernization and progress - as opposed to enabling the contestation and negotiation of these differences under democratic politics.

Consequently, Turkey's salient fissures, across ethnic and cultural lines (the issues of the Kurdish minority and subsequently of the place of religion in public 
life), exacerbated from the 1970 s onwards, meant that the state continued to be hostile to associational life and, by extension, to any sort of collective and civic action that was, or could be seen to be, asserting particularistic claims (Heper 1985). Thus, when the country's industrial elite established its own association, Turk Sanayiciler ve Isadamlari Dernegi-Turkish Industrialists' and Businesspersons' Association (TÜSİAD), in 1971, it had to couch its rationale in recognizable Kemalist discourse, which is in terms of aiming to contribute to Turkey's attainment of contemporary standards of civilization and affluence - rather than just to defending the legitimate interests of leading economic actors (Özbudun 1991).

Clamping down on the autonomy of the state university, when that autonomy was seen as incubating ideological clashes and national division, as in left and right violent confrontations across Turkish campuses in the 1970s, was, in the light of the above, eminently legitimate state action in pursuit of the national interest. This national interest ordained both the pacification of Turkish state campuses and the unhindered production of an educated cadre of technocrats that the nation continued to need for its uninterrupted advancement. Likewise, enlisting in this effort, Turkish business families and corporations, which were perceived to be loyal, enhanced the impact of control of the state university sector both quantitatively and qualitatively, as these newly founded institutions, well-endowed and efficient, could function as exemplars for their brethren - well integrated, predictable institutional pillars of Turkey's authoritarian corporatism. In sum, student radicalization in the 1970s and the wider fissures that it represented in Turkish society contributed to the reassertion of Turkey's authoritarian corporatism. Turkey's state elites considered that the founding of private universities would serve the national imperative for a depoliticized while advanced Turkish tertiary sector.

\section{The case of Greece}

In Greece, the first reform effort of higher education after the collapse of the military regime in 1974 was undertaken by the centre-right New Democracy (Nea Dimokratia [ND]) party in 1975-1976 and incorporated in Law 309/1976. ND sought to modernize education by enhancing its capacity both to create a democratic citizenship and an educated workforce that could prosper within the European Economic Community (Persianis 1998). Still, these reforms were denounced by the left, most prominently by the rising centre-left Panhellenic Socialist Movement (PASOK) and Greece's Communist Party (Kommounistiko Komma Ellados Communist Party of Greece [KKE]). They were portrayed as seeking to create a compliant workforce, preserve existing socio-economic distinctions and maintain Greece's international orientation as a loyal client state of the West and the USA in particular (Kazamias 1978). Actually, these criticisms echoed student protests and rhetoric during the dictatorship, culminating in the 1973 student 'Polytechnio' revolt against the Greek dictatorship's attempt to reform the university system along apolitical technocratic lines (Kornetis 2006, 178-9), just as the Evren regime did in the 1980s. From that perspective, the educational template that prevailed in Turkey in the 1980s, premised as it was on aggressive de-politicization and the acquisition of technocratic knowledge, fitted much better with this critique of the Greek left than the ND efforts which sought to balance - if imperfectly - both egalitarian and technocratic priorities. In addition, ND purged in 1975 the educational system of its most prominent dictatorship-era personalities. In retrospect, that would not be 
enough but rather a change in governance of the Greek universities would also be implemented once the left came into power in 1981. In particular, with PASOK becoming government in 1981, modernization and efficiency priorities would be compromised as obstacles to radical changes in the governance of higher education.

The PASOK government saw the university as a key democratization lever (Grollios and Kaskaris 2003). The university was seen as a place where democracy must be entrenched, as opposed to being violated, as it happened when the junta violently suppressed student demonstrations in 1973, if it were to address the national imperative for social equity and an emancipated popular will. Thus, Law 1268/82 enacted by PASOK provided for joint faculty and student-elected governing bodies, making it impossible for university rectors to be elected without the support of the voting blocs delivered by student political organizations. This meant that, henceforth, the Greek university would be essentially governed by alliances between faculty trade unions and the major student political organizations. These would elect the rectors accommodating their concerns and, by extension, those of the government which, in the case of PASOK in the 1980s, enjoyed strong representation with both groupings. As in Turkey, the institutional creation of a stakeholder, in this case the political student organizations, was meant to overwhelm the university establishments' perceived ideological opposition to the government of the day - albeit in Greece, the ideological roles were reversed with the Greek professoriate being seen as politically conservative.

This was part of an overall effort, undertaken by PASOK at the time, to encroach participatory democracy in all corporate entities of note, including stateowned enterprises (SOEs) and significant non-profit institutions. Legislation which mandated the participation of unions in the management boards of strategic SOEs spoke of serving 'the national interest and the social whole' (Papoulias and Lioukas 1995), of integrating SOEs in the wider struggle against Greece's domestic political and economic elite and its western patrons. The experience of the junta and the 1974 Cyprus crisis made the dominance of the popular will, expressed by the governing party in Greece's majoritarian parliamentary system, a supreme and unfettered goal to the point of intolerance to the voices of non-elected bodies, or to bodies governed through seniority and merit, as opposed through explicitly majoritarian outcomes (Voulgaris 2001).

Within this general thrust of 'socializing the state', the state university enjoyed a commanding position as: (i) the student movement was seen as a key factor behind the junta's collapse, and as the carrier of national will due to the lack of resistance to the regime by any other organized forces, (ii) key PASOK personnel were actually members of the 'Polytechnio generation' having participated in the uprising against the junta and (iii) being seen as representing the demands of this generation, PASOK could legitimately claim to represent the left and its aspirations in Greece at a time when the centre-right had become discredited and was seen as being on the losing side of history. Last but not least, all of these three factors acquired further weight as they were mediated by the natural claim of the academic community to provide intellectual leadership to Greek society.

PASOK's novel direction, as in the case of Turkey, powerfully interacted with an existing tradition in favour of the state being in command of education (Alivizatos 2007). The Greek constitution, long before PASOK came to power, had defined education as a core public good akin to public order and defence from the provision of which the state cannot abscond. This political tradition has been constitutionally 
encapsulated and maintained through Article 16, revised in the democratic constitution of 1975, which the centre-right ND introduced in Parliament. This article mandates that the provision of education is a core state mission and that such stateprovided education must serve the needs of inculcating the Greek national and citizenship consciousness. The same article prohibits the operation of institutions of higher education by private actors. In the parliamentary discussions, on the revised Article 16, both the then PASOK leader, Andreas Papandreou, and influential PASOK deputies argued for even stronger provisions, in the direction of extending the state monopoly in education to the secondary level and denying any foreigners or non-Greek bodies a role in the provision of education in Greece.

Article 16, although not voted by PASOK, by reaffirming the state monopoly in higher education, under PASOK's rule came to serve the imperative for a dominant and unquestioned paradigm in Greek higher education, albeit in the service of a radicalized, left-leaning nation. The innovation that PASOK introduced through Law $1268 / 82$ was to exercise this control through the participation of student organizations and faculty trade unions. PASOK, thus, simply continued this tradition, albeit within the contours of democratic majoritarianism, and student organizations implicitly endorsed it, although seeking to absorb it to their own worldview, a premise inherently inimical to pluralism. As it will become clear below, the effect was to compromise the other two goals articulated under the revision of Article 16 in 1975, namely the full self-governance of universities and the unhindered exercise of academic freedom.

To sum up, in both Greece and Turkey, subsequent to student radicalization in the 1970 s a major novel actor in university governance is introduced, the student movement in the case of Greece, private interests in the case of Turkey. In both Greece and Turkey, these new actors are seen as buttressing key regime goals; in Greece the confirmation and consolidation of the majority will, in Turkey the stabilization of the country and its re-dedication to its developmentalist purpose. These two commonalities, in both countries, much as they signal change they also underline continuity whereby the university, as a repository and diffuser of knowledge, is under indisputable national control and is aligned with national purpose.

\section{Higher education governance and academic freedom The case of Turkey}

After the economic liberalization programme of the Özal administration, the market opening mandated by Turkey's Association Agreement with the EU and the 1989 collapse of the Berlin Wall, Turkey's conglomerates were facing increasing competition at home from western European manufacturers and service providers. They also faced increasing competition, in western European markets, from manufactures from Central Eastern Europe, who availed themselves of the policy and macroeconomic stability, as well as the transfers which was the outcome of their status as pre-accession countries in the EU (Öniş and Türem 2002). Turkey's massive 2001 macroeconomic crisis powerfully underlined this necessity for an EU-induced governance and stability to Turkey's business elite. At the same time the positive reception of Turkey's candidacy for EU membership status by international investors cemented the link between a wider transformation of Turkey's polity, including democratization, and the ability of Turkey's conglomerates to survive and prosper in increas- 
ingly competitive home and international markets (Mousseau Yalcin 2006; Öniş and Bakır 2007). It was not that privileged access and carrying favour with the Turkish state were no longer important but rather that they were no longer sufficient to the strategic interests and orientation of Turkey's largest corporate holdings. As a result, they became increasingly willing to propose and vigorously defend changes in the Turkish polity that were anathema to the country's bureaucratic and military establishment (Yavuz 2010). Thus, this business class now challenged bureaucratic elites in terms of the definition of Turkish national interest, in the context of Turkey's EU vocation. As their Kemalist and corporatist credentials were impeccable, they were able to credibly propose alternative definitions of the national interest and the establishment of a pluralist public sphere. Overall, TÜSİAD, just as its early years in the 1970s, argued that its existence seeks to serve the common good - the difference being that by the 1990s it was willing and capable to disagree with Turkey's bureaucratic elite on what this good consisted of and on how it could be best pursued. Specifically, the Turkish corporate elite through its association, TÜSİAD, has claimed to speak of the national interest, not the class one, when it speaks of compliance to the EU. The TÜSİAD Report on Democratization signalled this willingness, on the part of business groups, to claim a leadership position within Turkey's corporatist hierarchy. The report was one of the most important policy documents of the late 1990s, which heralded the beginning of Turkey's most important political reform process challenging the ideological foundations of the country's Kemalist regime (Tanör 1997). The key desiderata proposed by this report were civilian control of the military, respect of minority rights and freedom of speech.

Turkey's private universities, some of the most prominent of which have been founded by TÜSIAD members, have strongly complemented TÜSİAD's stance by actively engaging in the ideological debates, which have characterized Turkey's politics since the late 1990s. Importantly they did so in the face of intense opposition both from the country's state establishment and extremist groups. As such, they became citadels of a discourse that would come to challenge the orthodoxies of republican Turkey, in terms both of its provenance and its contemporary practice on such explosive issues as the treatment of ethnic minorities. Through the establishment of faculties of humanities and social sciences, they were able to put forward an agenda of political pluralism which was viewed as necessary for Turkey's democratic consolidation.

Through the critical support of some private universities, taboo issues have been openly discussed for the first time. The 1915 Armenian massacres are a prime example. The 2005 conference on the Armenian issue, organized in Istanbul by three prominent universities, Bogaziçi, Sabanc1 and Bilgi University, the latter two of which are private, was a prime example for this. This conference, which hosted all opinions on one of Turkey's most sensitive issues, met with fierce reaction by nationalist media, bureaucrats and politicians. Although it had to be postponed once, due to mounting pressure and threats, the conference eventually took place in September 2005. It allowed for the expression of all academic views on the Armenian issue, including those which opposed the official Turkish narrative and triggered an unprecedented public debate on one of the most controversial topics of late Ottoman history. It also underlined the linkage between pluralism in governance arrangements and pluralism in expression. Bogaziçi, Turkey's leading elite state university, seen by many as enjoying relative, to other state peers, immunity from state intervention due to its privileged connections with the country's bureaucratic elite, 
many of whom count themselves as its alumni, was actually compelled by state interference to give up its designation as the venue for the conference on the Armenian Genocide. It was the private Bilgi University's willingness to take the baton that allowed the conference to take place.

In addition, private Turkish universities fostered academic research of non-Turkish civilizations in Anatolia. The study of ancient Greek, Byzantine and Armenian civilizations have never enjoyed the support of Turkey's state institutions. In line with the policies of several nation-states, Turkish authorities preferred not to support academic research on culture, art and history that were not classified as 'national'. Such research would highlight the multiethnic, multireligious and multicultural heritage of Anatolia, the assumed heartland of the Turkish Republic, and would allegedly undermine Turkish nationalist claims on Anatolia. Private universities run counter to this predilection, for a nationalist narrative by the Turkish state. The establishment of a well-endowed Research Center for Anatolian Civilizations (RCAC) by Koç University signalled increased interest in the study of non-Turkish civilizations of Anatolia. The mission statement of the RCAC identified, among its targets, to: (i) increase the awareness of the contributions and interactions Anatolian civilizations have had with other major world civilizations and (ii) develop and provide an educational forum in Turkey that focuses on current practices of international cultural heritage and museum studies. In view of these founding charter goals, the RCAC supported research on the ancient Greek, Byzantine, Armenian, Assyrian art, history, archaeology heritage of Anatolia, alongside the Seljuk and Ottoman. $^{2}$ The organization of a conference on 'Contemporary Perceptions of Byzantium' at Kadir Has University in November 2009 was another important example. While the organization of an academic conference on the Byzantine Empire was a novelty in itself, it was even more noteworthy that the opening lecture for the conference was given by Ecumenical Patriarch Bartholomew, the primus inter pares ecclesiastical leader for hundreds of millions of Orthodox Christians worldwide. This was a rare honour by a Turkish institution to the Patriarch, given the refusal of the Turkish authorities to recognize the Patriarch as anything else but the spiritual leader of Turkey's dwindling Greek Orthodox minority.

Moreover, private universities played a leading role in the promotion and facilitation of EU reform. While Turkey entered a new phase in its relations with the EU in 1999 and the prospect of EU membership looked more realistic than ever, private universities acted as reform catalysts. The establishment of European studies centres in several private universities (e.g. Bilgi University, Sabanc1 University and Bahçeșehir University) has contributed to the dissemination of European political ideals, as well as public advocacy of the reform process. Several seminars and conferences were organized in cooperation with European and US academic and policy institutions on issues such as democratization, human rights, the Kurdish issue, EU-Turkey relations and the role of media in democratization. Policy initiatives included issues as sensitive as education ${ }^{3}$ and justice.

Public involvement also included the mass media. Numerous faculty members of private universities undertook the role of public intellectual by becoming regular contributors to mainstream media, print and electronic. The creation of these 'safe havens' of academic freedom comprised a critical achievement of Turkish business groups. It led to the enrichment of the public discourse, a critical element of Turkey's democratic consolidation. The contribution of private higher education to the 
rise of a more pluralist public sphere can also be evaluated in contrast to incidents which manifest shortcomings in academic freedom within several state universities.

Secularist attempts to remove any traces of political Islam from the Turkish public sphere following the 1997 'soft' coup and the resignation of Turkey's first Islamist Prime Minister Necmettin Erbakan were also reflected in state university campuses. In March 2000, the rectorate of the state Inönü University in the eastern city of Malatya launched a purge operation of any books with Islamist content from the university library and the special library collection of the history department. The list of books withdrawn due to their suspected Islamist content included the world bestseller Sophie's World: A Novel about the History of Philosophy and all books in Arabic and Persian language. These books were eventually reinstated in the university library as they were found to have no Islamist leanings (Küçükcan and Gür 2009, 175-6). Yet academic freedom and pluralism were not.

Another clear example was the persecution of faculty members of state universities who expressed views against the mainstream. Prof. Atilla Yayla of Ankara's state Gazi University participated on 18 August 2006 in a panel on democratic reform organized in Izmir by the governing Adalet ve Kalkınma Partisi-Justice and Development Party's (AKP's) local youth organization (Yayla 2006). In his remarks, Yayla disputed the democratic and progressive credentials of early republican Kemalism. On the following day, a piece appeared in the local Izmir newspaper Yeni Asır, calling Yayla a 'traitor' for these comments. The issue was immediately taken over by Turkey's national media which raised a nationwide campaign against Yayla and his statements. Soon the government party AKP disowned him and his statements, and disciplinary procedures were launched against him at Gazi University. Prof. Yayla was suspended from his faculty post, while the Izmir prosecutor filed a case against him on the grounds of 'insulting Ataturk and his memory'.

The consolidation of academic freedom within private universities was symbolically underlined through a confrontation over the founder of republican Turkey. One of Turkey's leading private universities, Sabanc1 University, had long attracted the ire of nationalist groups for years due to its failure to erect an Ataturk monument in its campus, like any other Turkish university (Aș1k 2005). In November 2005, members of the youth organization of the extreme-left nationalist Workers' Party (Işçi Partisi) invaded the campus and protested the alleged anti-Ataturk policies of Sabanc1 University. They left only after leaving a bust of Ataturk in front of the university rectorate building. The university administration issued a public statement that 'despite these malevolent efforts and claims, our university will continue to follow Ataturk's path and educate liberal individuals defending university autonomy, knowledge and freedom of expression'. A few months later, an Ataturk monument was finally erected within the Sabanc1 University campus. Yet this monument differed greatly from its equivalents. It did not consist of a statue or bust of Ataturk but a handwritten statement of his on the question of pluralism:

I am not leaving any dogma, any frozen, moulded principle as moral legacy. My moral legacy is knowledge and reason.

Last but not least, the contribution of academic freedom within private to the enlargement of the space of open public discourse was also manifested through Internet access. Based on the laws which ban the smearing of Kemal Ataturk, Turkish courts have repeatedly banned popular Internet sites such as YouTube which 
contained allegedly illegal content. At times, banning the YouTube would also mean limitations to the access of several Google services. This situation put Turkey to the rather unhappy position of sharing a seat with China, Iran and Syria in the list of states imposing severe limitations to the use of Internet (Jones 2010). Yet several private Turkish universities appeared to circumvent the problem. By establishing direct links with their international Internet providers, they could escape limitations of Turkish courts. Hence, websites banned throughout Turkey remained accessible inside the campuses of private universities, such as Sabanc1 and Bilkent University.

\section{The case of Greece}

In Greece, during the same period of the 1990s and 2000s, when the 1982 reform became bedded down and its consequences were entrenched, one can observe - as in Turkey - the growing autonomy of the actor introduced by the reform in the governance of higher education, namely student organizations. Contrary to the Turkish experience, however, this growing autonomy has undermined the ability of the Greek university to protect and extend academic freedom.

The two main and interdependent governance features of Greece's higher education have developed as follows. First, the creation of a powerful rent-seeking coalition composed of student organizations, mainly Panellinia Agonistiki Spoudastiki Parataxi-Panhellenic Militant Students Group (PASP) and Dimokratiki Ananeotiki Protoporia-Democratic Renewal and Innovation (DAP), which are linked to Greece's two main parties, the centre-left PASOK and centre-right ND, and university rectors and other faculty, elected to lead universities, schools and departments, and who depend on their election on the bloc votes delivered by student organizations. ${ }^{4}$ Second, the emergence of the Greek university as a sui generis anomic institutional space with university authorities often neglecting their accountability for the management of personnel and financial resources, to Greek courts and state auditing authorities, and the ability of the Greek police and prosecutorial authorities to forestall, contain and prosecute common law crimes, such as the exercise of physical violence, theft, vandalism, drugs peddling, likewise being minimal.

Rent-seeking in Greek higher education, at its most fundamental, is a clientelistic transaction whereby the university authorities would grant to their clients - the student organizations who deliver their votes and get them elected in positions of authority - favours in exchange for votes. For the student organizations as voters, such favours include, indicatively, easy to manage exam schedules, less than demanding curricula on which these exams are based, passing grades, preferential access to postgraduate studies. For the students as organization leaders, in addition to the above-enumerated favours, the management of this transaction facilitates their careers, as they can secure fast-track advancement in one of Greece's political parties to which these student organizations are affiliated with. For faculty who engage on the other side of this transaction, other than the social goods of power over colleagues and societal recognition, the elevation to a position of authority with the indispensable help of student organizations provides privileged access to financial resources and - in some cases - significant opportunities for personal enrichment. Student organizations also have the ability, which they systematically employ, to physically intervene ${ }^{5}$ - even to the point of exercising violence - to derail the proceedings of the university's governing bodies and of university life, at large, through occupations of academic buildings and the disruption of lectures and 
conferences, under de facto impunity granted to them by 'asylum provisions' inscribed in law. This ability is a critical adjunct to the power of political student organizations, as it is used to: (i) threaten and/or exercise violence as a tool to enhance their power and influence over university authorities and (ii) impose the ideological conformity within the university space, which is critical to the legitimation of their own power. University authorities do not, in the main, challenge the concept and operationalisation of the university as an 'asylum' first and foremost because it is highly prized by their key constituents, the student organizations that elect them. However, they have a direct vested interest of their own not to do so. The concept of 'asylum' maintains the legitimacy of the claim that universities are unique in Greece in their entitlement to ignore or resist supervision and sanction by state authorities and judicial organs, even when such supervision and sanction are solidly grounded in the country's legal order. By safeguarding this legitimacy, rectors, university senates and departments leaderships are better able to arbitrarily manage academic and administrative affairs, particularly when these involve their particularistic self-interests.

As far as the impact on academic freedom is concerned, out of these two interacting modalities, of the university governed by a rent-seeking coalition between student organizations and faculty, and the university as an 'asylum', i.e. enjoying immunity from the Greek administrative and legal order, three main factors can be identified. First, the vulnerability that the state university exhibits, as the rent-seeking coalition that maintains in existence the asylum provisions, discourages pluralistic debate within the university, as they offer no protection to individuals and initiatives that would express views, which offend the sensibility of student organizations and/or other student factions of whatever ilk. Second, the limitations placed on university faculty to develop their curriculum in a way they see fit and in accordance with the advancements of the relevant academic disciplines. Third, the need to forestall the creation of a non-state university sector not least so that the ideological hegemony that sustains this rent-seeking coalition would remain unchallenged by the existence and operation of such institutions.

One can now examine these three factors that undermine pluralism in greater detail. Asylum provisions are not only exploited by student organizations that are partaking in the rent-seeking coalition but also by other student organizations and informal factions that want to promote an ideological agenda, which is independent of rent-seeking. Neither student organizations nor the departmental leaderships, university senates and rectors with which they rule the universities have an interest in challenging this latter category, however, as these more radicalized student factions, mostly found in the extreme left but also in the extreme right, drink from the same wellspring of legitimacy, namely the notion of the university as an inviolate, almost under any circumstances, space, as far as the Greek police and prosecutorial authorities are concerned.

Pluralistic expression has consequently suffered from the systematic disruption of visiting lectures and conferences considered provocative to the mores of the dominant left-wing political student associations and due to the fact that faculty, in a selfcensorship mode, would eschew the pursuit of such activities that would realistically be expected to provoke student ire and ultimately violence (Alivizatos 2007). Indicative of this tenor of Greek academic life have been the cancellation, after political student organization pressure, of a research programme undertaken by a professor of psychology at the University of Thessaloniki in 1988, due to misleading accusations 
by student organizations that it was sponsored by North Atlantic Treaty Organization (NATO), the interruption of a lecture on human rights violations in communist Eastern Europe at the University of Macedonia in 2001 and the break-up of a debate, with invited speakers being critical of the asylum provisions and practice, at Panteion University (Kampylis 2009). Although such disruption and violence have predominantly originated from left-leaning groups, they have by no means monopolized it, as the lack of essential order within campuses has been filled by groups across the ideological spectrum. Far-right groups have also stormed conferences which explored issues related to minority rights violations in Greece. One of the most recent examples was the interruption of a conference on the Chams at Panteion University in February 2008. All in all, violence directed against pluralistic expression within the Greek university indeed covers a wide ideological spectrum. However, the enabling source of this violence is the unwillingness of the universities' key stakeholders, its elected authorities and student organizations, to qualify the concept of asylum, which underpins their own institutional dominance. Our second factor, constraints imposed on curriculum development by student organizations, is particularly pronounced in Greece's older universities, which are geared towards employment in the public sector (Pesmazoglu 1994). In these universities, more than $75 \%$ of the graduates historically have sought employment in the state sector, thus curriculum did not need to incorporate disciplinary advancements that would impart marketable skills and know-how and/or sophisticated analytical skills to university graduates. Through this nexus of politicization and patronage, student organizations have undertaken to negotiate a narrow - textbook-based - curriculum and to take exams on an ever smaller sliver of this material and a convenient exam schedule to students affecting teaching programmes. Student organizations have bargained successfully to introduce curriculum changes and have often compelled faculty to give out pass grades to failing students. The concrete aim of having faculty engage in 'facilitating' students, Pesmazoglou notes, was 'given an ideological undertone: the catchword for years was against "intensification" of studies ... against strenuous efforts' (Pesmazoglu 1994, 295). This was due to the fact that 'the whole vocabulary of modernization, innovation, and adaptation of academic curriculum was automatically linked in the period of radicalization with capitalist and imperialist exploitation and anti European attitude prevailing up to the mid 1980s was its logical outcome' (Pesmazoglu 1994, 295). Pesmazoglu's findings have also been extensively corroborated by Greek press reports since (Koutsogianni 2010). By contrast, in Turkey, as noted above, a corollary of the alignment of the founders of private universities with the country's goal of EU accession, has accelerated curriculum advancement particularly in the humanities and the social sciences.

Moving on to the third factor forestalling academic freedom in Greek universities for student organizations, the university authorities and, in this case, the faculty trade union, Panellinia Omospondia Syllogon Didaktikou kai Erevnitikou Prosopikou-Panhellenic Federation of Academic and Research Staff Associations (POSDEP), a critical goal has been to derail the introduction of competition in higher education. This could be aimed either through the revision of Article $16^{6}$ or by granting professional rights to the operating private colleges in Greece, which have a franchise or other partnership arrangements, with third-country institutions of higher learning based in EU member country domiciles. ${ }^{7}$ Such competition would diminish the rent-seeking coalition's claim on resources, as a growing percentage of Greek students would be directed to institutions with governance 
arrangements that would not confer the same kind of leverage and control that faculty and student organizations have at the state universities, and could, potentially, become a template for a reform of governance arrangements in the state university system itself. This alliance has been rendered particularly effective by the threat or actual exercise of in-campus violence, which enjoys impunity, ${ }^{8}$ as well as the threat of off-campus protests. Such violence has been used strategically, particularly during the parliamentary debates, which were supposed to lead to revision of Article 16, which would have ended the state monopoly in higher education. Illuminatingly, the perspective of a pluralistic higher education in Greece, activated by the ND Karamanlis government of 2004-2009, in its effort to revise Article 16, was delegitimized by the spectre of involvement in education of business interests. The debate was framed by leftist parties, but also most eminent centre-left personalities originating from the university, who not only argued that the amendment of Article 16 aims at the commercialization of higher education and at undermining the principle that education is a public good but also at facilitating private actors, through the control of institutions of higher education, to alter Greece's ideological make-up. The idea that the university should privilege a particular ideological outlook as opposed to another, via the maintenance of a particular governance arrangement, which is hypothesized to enjoy majoritarian legitimation, goes to the heart of our analysis. It underlines the assessment of the actors involved in the governance of higher education in Greece that the survival of the rent-seeking coalition which they have fashioned over time is contingent upon the status of the state university as a monopoly provider of higher education. Only this monopoly status of the state university can keep in being the historical and ideological origins - those of the 17 November 1973 rebellion against the junta - that provide immunity to the rentseeking coalition from increased accountability from the Greek state and society. Inevitably, the preservation of these origins, in the foundations of the Greek state university, also privileges a particular ideological outlook and is thus inimical to academic freedom and pluralistic expression in general.

The fact that DAP, the centre-right student organization, is itself a major stakeholder in many universities in this rent-seeking coalition does not qualify our understanding. The reason is that DAP has partaken the rent-seeking benefits legitimized by a leftist ideological tradition in Greece (indeed not unlike trade unions associated with ND and powerful in state-controlled enterprises and the civil service) and has been rest content to abstain from the debate itself. Its autonomy as an actor, however, and those of the faculty that base their own power within Greece's various universities through their alliance with DAP, as opposed to PASOK's PASP, has been testified by the fact that during ND's reign in government, it pressed the government not to dilute student participation in the election of university authorities. ${ }^{9}$ In that respect, DAP has reflected its mother party, which has been mostly content to accept the ideological hegemony established by PASOK, in the 1980s and 1990s. In effect DAP, while paying lip service to supposed ideological and policy distinctions with PASP, actually partakes in similar rent-seeking coalitions to those that PASP, and its mother party PASOK's, ideological hegemony, has given shape to overtime.

\section{Conclusions}

In both Greece and Turkey, major political transitions at opposite directions towards democratization and authoritarianism, respectively, re-affirmed enduring statist 
traditions by denying autonomy to the existing universities and strengthening state control. This was aimed in Turkey through the institution of YÖK and in Greece through the maintenance of the state monopoly in higher education in combination with the participation of party-affiliated student organizations in rector elections. These regulatory innovations and continuities were contextualized by the primacy of the polity, the authoritarian, tutelary in Turkey, the democratic, majoritarian one in Greece, which mandated the mission of the university: technocratic development in Turkey, democratization and unhindered majority rule in Greece. In neither country was it considered legitimate and desirable that universities exercise autonomy to pursue their mission whether this mission was to be defined by the polity or by other social and economic stakeholders. In Turkey, however, private universities were allowed to come into being but at a time when their founders, Turkey's business families, were both dependent on the authoritarian state and seen as loyal participants in the project of building a stable, authoritarian and modern Turkish state and economy.

In a dynamic process, both in Greece and in Turkey, the capacity of stakeholders to use governance arrangements, granted to them by the state, to suit their own evolving needs and aims, and employing to this task leverage they did not possess, at the time when these governance arrangements were first instituted, played itself out, with contrasting results for academic freedom. In Turkey, the founders of private universities availed themselves of their greater credibility and declining dependence on the state, together with the emergence of a national goal which was conformable with their strategic imperative, namely EU accession, to challenge the ideological primacy and power motives of the bureaucratic elites that first opened the doors of higher education to them. While business groups as founders and owners of academic institutions are usually considered as obstacles to academic freedom, they have contributed to the latter's reinforcement in Turkey. In Greece, the rent-seeking prowess and the motives that materialized due to rent-seeking led a powerful coalition of political student organizations, faculty trade unions and the university leaderships that they jointly promoted, to undermine academic freedom. Intolerance towards the expression of views in the university deemed hostile to student organizations and/or factions, curriculum stagnation and the suppression of governance reform of the state university and the emergence of competing governance arrangements in Greek higher education, which would not be under the ideological and administrative control of the rentseeking coalition, have been the consequences.

\section{Acknowledgement}

The authors thank Ms. Damla Cihangir for her valuable contribution to the completion of this study.

\section{Notes}

1. Indicatively see (Altbach 2011) and (Mazawi 2011).

2. In an interesting contrast, the Museum of Anatolian Civilizations in Ankara hosted only items from those Anatolian Civilizations which could not be claimed by competing nationalisms, Phrygian, Hittite and Urartu art.

3. An example of this was the education reform initiative (ERI), a project launched within the Istanbul Policy Center at Sabanci University with the aim to improve education policy and decision-making through research, advocacy and monitoring. ERI is committed to quality K-12 education for all. 
4. The collusion between student organisation and university authorities received scholarly attention subsequent to the 1982 reform and up to currently, see indicatively Grant (1986, 17-31), Pesmazoglu (1994).

5. Similarly, the routine disruption of academic proceedings, conferences and lectures has also been widely discussed in the Greek press. Indicatively, Lakasas (2009).

6. On the question of Article 16, also see Psacharopoulos (2003).

7. POSDEP, rectors, student organizations and the parties of the Greek communist parties, KKE and Synaspismos Rizospastikis Aristeras-Coalition of the Radical Left (SYRIZA), have formed an alliance to resist - successfully - the repeal of Article 16. Indicatively, see Mandravelis (2006).

8. POSDEP's previous leadership, which intensely interacted with student organizations to derail the reforms of higher education by the ND government, has argued that the management of asylum provisions - which determine whether universities would call or not the police to quell disturbances, violence or even criminality - should not be the province only of rectors but should continue to be co-determined with student representatives, see Apekis (2007).

9. This was related to one of the two authors in spring 2006 by an advisor to the then Greek prime minister, Constantine Karamanlis.

\section{Notes on contributor}

Ioannis N. Grigoriadis is an Assistant Professor at the Department of Political Science, Bilkent University. Between 2004 and 2009, he taught at Sabanci University, Isik University and the University of Athens. His research interests include European, Middle Eastern and energy politics, nationalism and democratisation. His recent publications include Trials of Europeanization: Turkish political culture and the European Union (2009); Redefining the nation: The shifting boundaries of the 'other' in Greece and Turkey, Middle Eastern Studies (2011); Mutations of Turkish nationalism: From Ulusalcılik to the Ergenekon affair, Middle East Policy (2010); Europe and the impasse of centre-left politics in Turkey: Lessons from the Greek experience, Journal of Balkan and Near Eastern Studies (2010); Friends no more?: The rise of Anti-American nationalism in Turkey, Middle East Journal (2010); Islam and democratization in Turkey: Secularism and trust in a divided society, Democratization (2009) and The Orthodox Church and Greek-Turkish relations: Religion as source of rivalry or conciliation?, Religion and politics in Europe, the Middle East and North Africa (2009).

Antonis Kamaras holds a BA degree in Government from Connecticut College, an MSc degree in political theory and an MPhil degree in International Relations and International Political Economy from the London School of Economics (LSE). He has been a Research Officer at the Hellenic Observatory of the European Institute of the LSE, in the academic year 2000-2001, where he published research on the internationalization of Greek business in the Balkans and on market reforms and the resulting urban disparity between Thessaloniki and Athens. He commenced his career in Greek finance in the early 1990s, in Sofia, Bulgaria, where he established one of the first units of the Greek financial sector to operate in the Balkans, following the disintegration of the Eastern Bloc. Subsequently, he became an advisor to the Governor of National Bank of Greece (NBG), Greece's largest commercial bank, where he was mostly engaged with NBG's regional expansion strategy. He concluded his career in Greek banking with a three-year stint in Istanbul, Turkey, where he participated in the acquisition, in 2006, by NBG of Finansbank, Turkey's fourth largest privately-owned financial institution. The acquisition of Finansbank was the largest ever cross-border investment by a Greek corporation and a milestone in Greek-Turkish relations. Since January 2011, he has been an advisor to the Mayor of Thessaloniki, Mr Yiannis Boutaris, with a focus on the city's economic growth agenda and its international relations.

\section{References}

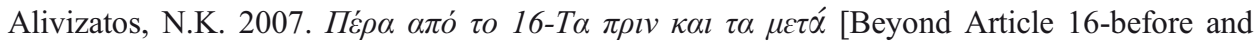
after]. Athens: Metehmio. 
Altbach, P.G. 2011. Reforming higher education in the middle East-and elsewhere. International Higher Education 64: 2-3.

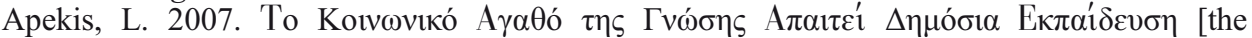
Social Good of Knowledge Requires Public Education]. In $H$ Y $\varepsilon \rho \sigma \pi \imath \sigma \eta \tau$

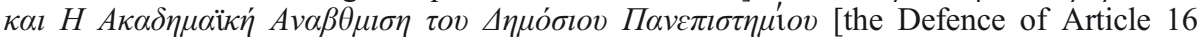
and the Academic Upgrade of the Public University]. Athens: Nikos Poulantzas Institute.

Așık, M. 2005. Sabanc1 Hatirası. Milliyet, 10/9/2005.

Bianchi, R. 1984. Interest groups and political development in Turkey. Princeton, NJ: Princeton University Press.

Grant, G.H. 1986. University reform in Greece: 1982 and after. Journal of Modern Greek Studies 4, no. 1: 17-31.

Grollios, G., and I. Kaskaris. 2003. From socialist-democratic to 'Third Way' politics and rhetoric in Greek education (1997-2002). Journal for Critical Education Policies 1, no. 1.

Heper, M. 1985. The state tradition in Turkey. Walkington: Eothen Press.

Jones, D. 2010. Google feud spotlights internet censorship in Turkey. http://www.dw-world. de/dw/article/0,5729923,00.html.

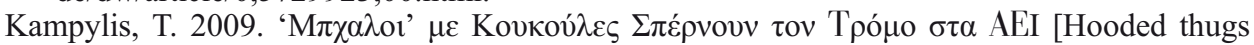

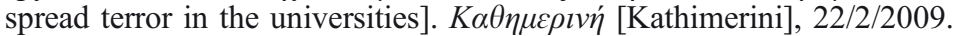

Karran, T. 2009. Academic freedom in Europe: Time for a Magna Charta? Higher Education Policy 22, no. 2: 163-89.

Kazamias, A.M. 1978. The politics of educational reform in Greece: Law 309/1976. Comparative Education Review 22, no. 1: 21-45.

Kornetis, K., 2006. Student resistance to the greek military dictatorship: Subjectivity, memory and cultural politics, 1967-1974. European University Institute.

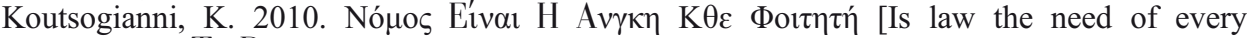
student?]. To Bín [To Vima], February 7.

Küçükcan, T. and Gür, B. 2009. Türkiye'de Yükseköğretim: Karşılaştırmalı Bir Analiz. SETA, Ankara.

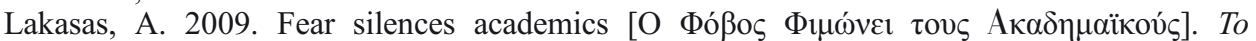
Vima, April 5.

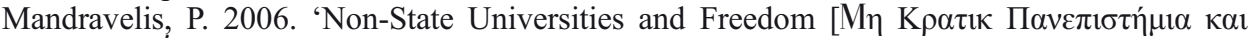

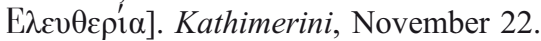

Mazawi, A.E. 2011. The Arab spring: The higher education revolution that is yet to happen. International Higher Education 65: 12-3.

Menon, M. E. 2003. Student involvement in university governance. A need for negotiated educational aims? Tertiary Education and Management 9, no. 3: 233-46.

Mousseau Yalcin, D. 2006. Turkey and the EU: The importance of markets. Survival 48, no. 3: $97-108$.

Öniş, Z., and C. Bakır. 2007. Turkey’s political economy in the age of financial globalization: The significance of the EU anchor. South European Society and Politics 12, no. 2: $147-64$.

Öniş, Z., and U. Türem. 2002. Entrepreneurs, democracy, and citizenship in Turkey. Comparative Politics 34, no. 4: 439-56.

Özbudun, E. 1991. The post-1980 legal framework for interest group associations. In Strong state and economic interest groups: The post-1980 Turkish experience, ed. M. Heper, 41-53. Berlin: Walter de Gruyter.

Papoulias, D.B., and S. Lioukas. 1995. Participation in the management of public enterprises: Experience from Greek utilities. Annals of Public and Cooperative Economics 66, no. 3: 275-98.

Parla, T., and A. Davison. 2004. Corporatist ideology in kemalist Turkey: Progress or order? Syracuse, NY: Syracuse University Press.

Persianis, P. 1998. Compensatory legitimation in Greek educational policy: An explanation for the abortive educational reforms in Greece in comparison with those in France. Comparative Education 34, no. 1: 71-83.

Pesmazoglu, S. 1994. Government, ideology and the university curriculum in Greece. European Journal of Education 29, no. 3: 291-304.

Psacharopoulos, G. 2003. The social cost of an outdated law: Article 16 of the Greek constitution. European Journal of Law and Economics 16, no. 2: 123-37. 
Singer, A. 2008. The persistence of philanthropy in Turkey, 2008 Sakıp Sabancı International Research Award Essay. Istanbul: Sabanci University.

Tanör, B. 1997. 1997 TÜSIAD report: Perspectives on democratization in turkey. Istanbul: TÜSİAD.

Vere, A. 2007. Freedom of association and staff participation in higher education decisionmaking: A review. Geneva: International Labour Organization.

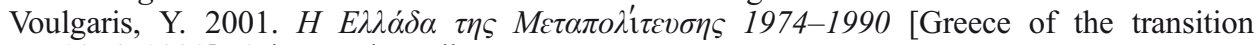
1974-1990]. Athens: Themelio.

Yavuz, D. 2010. Testing large business's commitment to democracy: Business organizations and the Secular-Muslim conflict in Turkey. Government and Opposition 45, no. 1: $73-92$.

Yayla, A. 2006. Freedom of expression in Turkey. International Herald Tribune, December 6. 